\title{
PENDIDIKAN MULTIKULTURAL SEBAGAI UPAYA PENGUATAN NILAI KARAKTER TOLERANSI PADA ANAK USIA DINI DI PERUMAHAN PNS KOTA METRO
}

\author{
Nina Tisnawati \\ Universitas Muhammadiyah Metro \\ Ninaumiufaira@gmail.com
}

\begin{abstract}
ABSTRAC
This research is motivated by the housing environment of the meto Lampung city civil society which has a diverse society of ethnicity and religion, in a multikutural community environment certainly makes early childhood sometimes ask about children in different environments with themselves, so parents give explanations to children that aims to strengthen the character values of tolerance in children from an early age that needed a strong explanation so that early childhood can understand about tolerance, the purpose of this study is how to multicultural education of young children in civil servants in the city of Metro, how to instill character values tolerance in early childhood in Metro City civil servant housing, the location of this study is in the civil service housing Metro Lampung city, this research method is a qualitative research with descriptive approach analysis type,multicultural education in the housing of civil servants in the city of metro is done individually and individually educated groups that are by way of parents giving direction to the child in each question the child says that the habits of his friends are different from him that's where the role of parents provides multicultural education to children and from groups of mobile libraries that the purpose of holding a mobile library so that children can play together learn together without distinguishing between ethnic and religious differences between them in order to make early childhood in the housing environment of the PNS Metro city embedded the value of tolerance in a social life full of love, peace and full interfaith affection and have a Bhineka Tunggal Ika soul in everyday life
\end{abstract}

Keywords: Multicultural, Character of tolerance, early childhood

\begin{abstract}
ABSTRAK
Penelitian ini dilatarbela kangi oleh lingkunagn perumahan PNS kota meto lampung yang memiliki masyarakat beragam dari suku dan agama, dalam lingkungan masyarakt yang multikutural tentu membuat anak usia dini terkadang bertanya mengenai anak-anak dilingkungannya yang berbeda dengan dirinya, sehingga para orang tua memberikan penjelasan kepada anak-anak yang bertujuan untuk mengauatkan nilai karakter toleransi pada anak-anak sejak usia dini yang dibutuhkan penjelasan yang kuat agar anak usia dini dapat memahami tentang toleransi, tujuan penelitian ini tentang bagaimana pendidikan multicultural anak usia dini di perumahan PNS kota Metro, bagaimana penanaman nilai karakter toleransi pada anak usia dini di perumahan PNS kota Metro, lokasi penelitian ini adalah di perumahan PNS kota Metro Lampung, metode penelitian ini adalah penelitian kualitatif dengan jenid spendekatan deskriptif
\end{abstract}


analisis, pendidikan multicultural di perumahan PNS kota metro di lakukan secara individu dan kelompok pendidikan secara individu yaitu dengan cara orang tua memberikan pengarahan kepada anak disetiap pertanyaan anak yang mengatakan bahwa kebiasaan kawannya berbeda dengan dirinya disitulah peran orangtua memberikan pendidikan multicultural kepada anak dan dari kelompok perpustakaan keliling yang tujuan diadakan perpustakaan keliling supaya anakanak bisa beramain bersama belajar bersama tanpa membedakan perbedaan diantara mereka baik suku maupun agama yang bertujuan agar anak usia dini di lingkungan perumahan PNS kota Metro tertanam nilai toleransi dalam kehidupan bermasyarakat yang penuh rasa kasih sayang, cinta damai dan penuh kasih sayang antar semama dan memiliki jiwa BINEKATUNGGALIKA dalam kehidupan sehari-hari

Kata Kunci: Multukultural, Karakter toleransi, anak usia dini

\section{A. PENDAhuluan}

Indonesia merupakan Negara yang multicultural, yaitu Negara yang kaya akan suku bangsan ras serta budaya yang sanagat beragam. Pada hakikatnya pendidikan multicultural harus dikenalkan kepada setiap orang terlebih pada anak usia dini. pada masa anak usia dini pengenalan akan multicultural sangat di anjurkan, karena pada masa anak usia dini adalah di mana anak mulai belajar mengenaal lingkungan sekitar sehingga anak-anak mulai akan melihat perbedaan tradisi/kebiasaan ketika di dalam rumah dan di luar rumah. Pentingnya pendidikan multicultural pada anak usia dini berdampak pada tingginya kesadaran, partisipasi dan kebutuhan masyarakat terhadap pentingnya pendidikan anak usia dini dalam menghasilkan sumber daya yang bermaktub dalam pasal 1 ayat (1) undang-undang nomor 20 tahun 2003 tentang Sistem Pendidikan Nasiaonal ${ }^{1}$. Pendidikan multicultural sudah ada anjuran sejak zaman Rosululloh SAW ketika tinggal di kota madinah kemudian Allah SWT menurunkan wahyu kepada Rosululloh SAW, Allah berfirman dalam surat al Hujurat ayat 13 yang artinya :

"Hai manusia, Sesungguhnya Kami menciptakan kamu dari seorang laki-laki dan seorang perempuan dan menjadikan kamu berbangsa - bangsa dan bersuku-suku supaya kamu saling kenal-mengenal. Sesungguhnya orang yang paling mulia diantara kamu disisi Allah ialah orang yang paling taqwa diantara kamu. Sesungguhnya Allah Maha mengetahui lagi Maha Mengenal.” (QS. Al Hujurot:13)²

\footnotetext{
${ }^{1}$.Martimin Sabrin dan Jamilah sanan, "Panduan pendidikan Anak Usia Dini”" (Jakarta: Gaung Persada press, 2010) h.3

${ }^{2}$ Departemen Agama RI, “al Qur’an dan Terjemahnya” (Bandung: PT al Cordoba,2013), Cet Ke, 1 h. 517

Volume 1 No 1 2019, J-Sanak_Jurnal Kajian Anak | 38
} 
Dari ayat di atas sudah jelas bahwa pendidikan multicultural sanagt penting karena Allah menciptakan manusia besuku-suku dan di setiap suku memiliki budaya sendiri kita sebagai manusia harus saling dan memahami budaya setiap suku agar manusia makin mencintai rabbNya begitu kuasa Allah SWT menciptakan manusia dengan berbagai suku agar kita saling mengenal serta menghargai sesama dan tidak bermusuhan atau saling menjelekan suku satu dengan suku lainnya.

Perumahan PNS kota metro adalah lingkungan perumahan yang masyarakat di dalamnya banyak berbagai suku dari berbagai pulau di Indonesia seperti suku jawa, lampung, bali, sunda banten, batak, dan lain-lain, sehingga pendidikan multicultural sangat penting untuk di kenalkan pada anak usia dini agar mereka bertolerensi terhadap kebiasaan orang-orang yang ada di lingkungannya dan mengenalkan suku meraeaka kepada anak-anak. Pendidikan multicultural sngat penting di tanamkan pada adak usia dini di lingkungan perumahan PNS kota metro karena bnyak sekali keuntungan yang akan di dapatkan diantaranya adalah penguatan karakter toleransi pada masyarakat yang tinggal di dalamnya terlebih pada anak usia dini, penanaman karakter toleransi membuat anak-anak salng menghargai satu sama lain dan memahami keaneragaman suku budaya dan agama di antara mereka

Dari paparan latar belakang yang sudah tertulis di atas maka penelitian ini dapat dirumuskan sebagai berikut; 1) bagaimana pendididikan multicultural anak usia dini di perumahan PNS kota Metro. 2) bagaimana nilai karakter toleransi pada anak usia dini di perumahan PNS kota metro. Pendidikan multikulturan pada penelitian ini bertujuan untuk mendidik anak-anak agar dapat menghargai nilai-nilai dan budaya orang lain, membantu anak-anak untuk berfungsi secara optimal dalam situasi multicultural, mengembangkan konsep diri yang positif pada anak-anak yang mengalami diskriminasi ras, serta memberanikan anak-anak untuk merasakan pengalaman orang lain yang berasal dari budaya yang berbeda-beda dan bekerja sama sebagai bagian yang unik dari satu komunitas dan menguatkan nilai karakter toleransi pada anak-anak sejak dini.

\section{B. METODE PENELITIAN}

Lokasi penelitian ini adalah di perumahan PNS kota metro kelurahan yosomulyo RW/RT 15/46 gang prabu 2 kecamatan Metro pusat kota metro lampung. Metode penelitian dalam penelitian ini adalah kualitatif dan jenis pendekatan penelitian adalah deskriptif analisis dimana 
penulis mengumpulkan data bukan melalui angka namun menggunakan penjelasan sejelas jelasnya dan sedalam-dalamnya

\section{PEMBAHASAN \\ 1. Pengertian Pendidikan}

Pengertian pendidikan sudah banyak sekali definisi dari para ilmuan yang berbeda-beda dan di sini penulis mengambil kesimpulan dari pengerrtian pendidikan yaitu Pendidikan adalah usaha sadar yang dilakukan oleh keluarga, masyarakat, dan pemerintah, melalui kegiatan bimbingan, pengajaran, dan atau latihan, yang berlangsung di sekolah dan di luar sekolah sepanjang hayat, untuk mempersiapkan peserta didik agar dapat memainkan peranan dalam berbagai lingkungan hidup secara tepat di masa yang akan datang. ${ }^{3}$

Tiller (2002) mengemukakan bahwa pendidikan itu memiliki batasa-batasan yang berbeda menurut fungsinya, dan ada bebrapa fungsi dari pendidikan adalah sebagai berikut:

a) Pendidikan sebagai proses Transformasi budaya

Sebagai proses tranformasi budaya, pendidikan diartikan sebagai kegiatan pewarisan budaya dari satu generasi kegenerasi yang lain, seperti bayi lahir yang sudah ada dalam lingkungan budaya tertentu. Didalam lingkungan masyarakat dimana seorang bayi dilahirkan mendapatkan kebiasaan-kebiasaan, larangan-larangan, anjuran dan tradisi tertentu dalam lingkungannya seperti yang dikendaki masyarakat yang ada di sekitarnya. Hal-hal tersebut menganai banyak hal seperti banyak hal, cara menerima tamu, makanan, istirahat, bercocok tanam, bekerja, perkawinan dan alin sebagainya, nilai-nilai kebudayaan tersebut mengalami proses transformasi dari generasi tua ke generasi muda.ada 3 bentuk transformasi yaitu nilai-nilai yang masih cocok di teruskan misalnya nilai-nilai kejujuran, rasa tanggung jawab dan lain-lain, dan yang kurang cocok di perbaiki misalnya tata cara perkawinan, dan yang tidak cocok diganti misalnya pendidikan seks yang dulu dianggap masih tabu menjadi pendidikan seks melalui pendidikan formal.disini tampak jelas bahwa proses pewarisan budaya tidak mengekalkan budaya semata-mata secara estafet namun pendidikanlah yang justru mempunyai tugas menyaiakan peserta didik untuk hari esok

${ }^{3}$ Dosen sosiologi.Com Dalam: http://dosensosiologi.com/pengertian-multikultural-latar-belakang-ciri-danbentuk, di akses pada 03 agustus 2019 , pukul 09:30 WIB

Volume 1 No 1 2019, J-Sanak_Jurnal Kajian Anak | 40 


\section{b) Pendidikan sebagai proses pembentukan pribadi}

Tirtaraharja mengemukakan bahwa pendidikan sebagai sebuah proses pembentukan pribadi, pembentukan diartikan sebagai suatu kegiatan sistematis dan sistemik yang terarah kepada terbentuknya kepribadian peserta didik. Proses pembentukan pribadi melalui dua sasaran yaitu pembentukan pribadi bagi yang mereka yang belum dewasa oleh mereka yang sudah dewasa dan bagi mereka yang sudah dewasa atas usanya sendiri. Keduanya bersifat alamiyah dan menjadi keharusan. Bayi yang baru lahir kepribadiannya beleum terbentuk, belum mempunya warna dan corak uktuk kepribadiannya tertentu, ia merupakan individu belum suatu pribadi. Untuk menjadi suatu pribadi perlu mendapatkan banyak bimbingan, latihan-latihan dan pengalaman melalui bergaul dengan lingkungannya, khususnya dengan lingkungan pendidikan. Bagi mereka yang sudah dewasa tetep di tuntut adanya pengembangan diri agar kualitas kepribadian serempak dengan meningkatnya tantangan hidup yang selalu berubah. Dalam hubungan ini di kenal apa yang disebut pendidikan sepanjang hidup, pembentukan pribadi mencangkup pendidikan cipta rasa dan karsa (Kognitif, Afektif, dan psikomotorik) yang sejalan dengan pengembangan fisik, dalam pssisi manusia yang serba terhubung, pendidikan pribadi meliputi pengembangan penyesuaian diri terhadap lingkungan, terhadap tuhan dan diri sendiri

\section{c) Pendidikan Menurut Undang-undang Sistem pendidikan Nasional}

Undang-undang pendidikan Nsional mengemukakan bahwa pendidikan adalah usaha sadar dan terencana untuk mewujudkan suasana belajar dan proses pembelajaran agar peserta didik secara aktif mengembangkan potensi dirinya untuk memiliki spiritual keagaman, pengendalian diri, pengendalian diri, kecerdasan, akhlak mulia, keterampilan yang diperlukan dirinya masyarakat bangsa dan Negara. Pendidikan nasional berfungsi mengembangkan kemampuan dan membentuk watak serta perdaban bangsa yang bermartabat dalam rangka mencerdaskan kehidupan bangsa, bertujuan untuk berkembangnya potensi peserta didik agar menjadi manusia yang beriman bertaqwa kepada Tuhan Yang Maha Esa, berakhlak mulia, sehat, berilmu cakap, kreatif mandiri, dan menjadi warga Negara yang demokratis serta bertanggung jawab ${ }^{4}$

\section{d) Pendidikan Secara Sistem}

${ }^{4}$ Undang-Undang Sisdiknas 2003, Bab I Pasal I Ayat I dan Bab 2 Pasal 3

Volume 1 No 1 2019, J-Sanak_Jurnal Kajian Anak | 41 
Pendidikan merupakan suatu totalitas atau satu kesatuan yang terdiri dari komponenkomponen yang satu sam lain tidak dapat di pisahkan dan berhubungan secara fungsional dalam rangka mencapai tujuan. Komponen-komponen yang ada dalam pendidikan adalah (1) Tujuan Pendidikan Islam, (2) Peserta Didik,(3) Pendidik (4) Isi Pendidikan (Kurikulum) (5) Fasilitas Pendidikan (6) Interaksi edukatif, komponen-komponen tersebut akan sangat bermakna apa biala terjadi keterkaitan satu sama lainnya dan saling berhubungan ${ }^{5}$

\section{Pengertian pendidikan multikultural}

Secara sederhana multikulturalisme berarti "keberagaman budaya". Istilah multikultural ini sering digunakan untuk menggambarkan tentang kondisi masyarakat yang terdiri atas keberagaman agama, ras, bahasa, dan budaya yang berbeda. Selanjutnya, dalam khasanah keilmuan istilah multikultural ini dibedakan ke dalam beberapa ekspresi yang lebih sederhana, seperti pluralitas (plurality) mengandaikan adanya "hal-hal yang lebih dari satu (many)", keragaman (diversity) menunjukkan bahwa keberadaan yang "lebih dari satu" itu berbeda-beda, heterogen, dan bahkan tidak dapat disamakan, dan multikultural (multicultural) itu sendiri. ${ }^{6}$

Secara epistmologis multikulturalisme dibentuk dari kata "multi" (banyak), "kultur" (budaya), dan "isme" (aliran/paham). Secara hakiki dalam kata itu terkandung pengakuan akan martabat manusia yang hidup dalam komunitasnya dengan kebudayaannya masing-masing yang unik. Dengan demikian, setiap individu merasa dihargai sekaligus merasa bertanggung jawab untuk hidup bersama komunitasnya. Pengingkaran suatu masyarakat terhadap kebutuhan untuk diakui merupakan akar dari segala ketimpangan dalam berbagai bidang kehidupan.

Pengertian multikulturalisme mengandung dua pengertian yang sangat kompleks, yaitu "multi" yang berati jamak atau plural, dan "kulural" yang berarti kultur atau budaya. Istilah plural mengandung arti yang berjenis-jenis, karena pluralisme bukan sekedar pengakuan akan adanya hal yang berjenis-jenis tetapi pengakuan tersebut memiliki implikasi politis, sosial, ekonomi, dan budaya. Dalam pengertian tradisonal tentang multikulturalisme memiliki dua ciri utama; pertama, kebutuhan terhadap pengakuan (the need of recognition). Kedua, legitimasi

${ }^{5}$ Suryana, Dadan,” Pendidikan Anak Usia Dini Teori dan praktik, (Padang:UNP Pres,2013),h. 15-18

${ }^{6}$ Musthofa dalam https://pengertian multikultural menurut para ahliid.wikipedia.org/wi diakses di metro pada tanggal 05 Agustus 2019 pukul 09:00 WIB 
keragaman budaya atau pluralisme budaya. Dalam gelombang pertama multikulturalisme yang esensi terhadap perjuangan kelakuan budaya yang berbeda (the other ${ }^{7}$

Pendidikan multikultural adalah sebuah tawaran model pendidikan yang mengusung ideologi yang memahami, menghormati, dan menghargai harkat dan martabat manusia di manapun dia berada dan dari manapun datangnya (secara ekonomi, sosial, budaya, etnis, bahasa, keyakinan, atau agama, dan negara). Pendidikan multikultural secara inhern merupakan dambaan semua orang, lantaran keniscayaannya konsep "memanusiakan manusia". Pasti manusia yang menyadari kemanusiaanya dia akan sangat membutuhkan pendidikan model pendidikan multikultural ini. ${ }^{8}$

\section{Pengertian Anak Usia Dini}

Pengertian anak usia dini secara umum adalah anak-anak di bawah usia 6 tahun. Pemerintah melalui UU Sisdiknas mendifinisikan anak usia dini adalah anak dengan rentang usia 0-6. Para ahli menyimpulkan bahwa anak usia dini yang sedang dalam tahap pertumbuhan dan perkembangan, baik fisik maupun mental. Masa anak usia dini sering disebut dengan istilah "golden age" atau masa emas. Pada masa ini hampir seluruh potensi anak mengalami masa peka untuk tumbuh dan berkembang secara cepat dan hebat. Perkembangan setiap anak tidak sama karena setiap individu memiliki perkembangan yang berbeda. ${ }^{9}$

Selain pengertian anak usia dini juga memiliki karakter yang luar biasa karena Masa usia dini merupakan masa ketika anak memiliki berbagai khasan dalam bertingkah laku. Sebagai orang tua dan pendidik wajib mengerti karakteristik-karakteristik anak usia dini, supaya segala bentuk perkembangan anak dapat terpantau dengan baik. Berikut ini adalah beberapa karakteristik anak usia dini menurut berbagai pendapat:

a. Unik, yaitu sifat anak itu berbeda satu sama lain. Anak memiliki bawaan, minat, kapabilitas dan latar belakang kehidupan masing-masing

\footnotetext{
${ }^{7}$ Hanafi," Saintifika Islamica :Jurnal Kajian Islam UIN Jogjakarta, Saintifika Islamica volume 3 no2 perode juli-Desember 2016 ISSN:Vol 32407No.- 053X2 h. 170

${ }^{8}$ Zakwan Priaji, Dalam: http://zakwaan-priaji.blogspot.com/2013/07/pengertian-pendidikanmultikultural.html, metro 20 mei 2019, 14.00

${ }^{9}$ Kamus Besar Bahasa Indonesia Daring (Dalam Jaringan), Mansur, Pendidikan Anak Usia Dini Dalam Islam, Pustaka Pelajar, Yogyakarta, 2005.
} 
b. Egosentris, yaitu anak lebih cendrung melihat dan memahami sesuatu dari sudut pandang dan kepentingannya sendiri. Bagi anak sesuatu itu sepanjang hal tersebut berkaitan dengan dirinya

c. Aktif dan energik, yaitu anak lazimnya senang melakukan berbagai aktivitas. Selama terjaga dari tidu, anak seolah-olah tidak pernah lelah, tidak pernah bosan, dan tidak pernah berhenti dari aktivitasnya. Terlebih lagi kalau anak dihadapkan pada aktivitas yang baru.

d. Rasa ingin tahu yang kuat dan antusias terhadap banyak hal. Yaitu anak cendrung memerhatikan, membicarakan, dan mempertanyakan berbagai hal yang sempat dilihat dan didengarnya terutama terhadap hal-hal baru

e. Eksploratif dan berjiwa petualang, yaitu anak terdorong oleh rasa ingin tahu yang kuat dan senang menjelajah, mencoba dan mempelajari hal-hal yang baru.

f. Spontan, yaitu prilaku yang ditampilkan anak umumnya relative asli dan tidak ditutuptutupi sehingga merefleksikan apa yang ada dalam perasaan dan pikirannya.

g. Senang dan kaya fantasi, yaitu anak senang dengan hal-hal yang imajinatif. Anak tidak saja senang dengan cerita-cerita khayal yang disampaikan oleh orang lain, tetapi juga ia sendiri juga senang bercerita kepada orang lain.

h. Masih mudah frustasi, yaitu anak masih mudah kecewa bila menghadapi sesuatu yang tidak memuaskan. Ia mudah menangis dan marah bila keinginannya tidak terpenuhi.

i. Masih kurang pertimbangan dalam melakukan sesuatu, yaitu anak masih kurang memiliki pertimbangan yang matang termasuk berkenaan dengan hal-hal yang mambahayakannya.

j. Daya perhatian yang pendek, yaitu anak lazimnya memiliki daya perhatian yang pendek, kecuali terhadap hal-hal yang secara instrinsik menarik dan menyenangkan.

k. Bergairah untuk belajar dan banyak belajar dari pengalaman yaitu anak melakukan banyak aktivitas yang menyebabkan terjadinya perubahan tingkah laku pada dirinya. 
1. Semakin menunjukkan minat terhadap teman, yaitu anak mulai menunjukkan untuk bekerjasama dan berhubungan dengan temannya. ${ }^{10}$

Setelah mengetahui pengertian dan karakteristik pada anak usia dini, anak-anak sangatlah tepat jikat di ajarkan bagaimana bertoleransi pada sesama, anak usia dini memiliki sifat ingin tahu yang tinggi kenapa kawannya beda dengan yang lain,senang akan fantasi jika melihat hal-hal yang menyenangkan mungin pada suatu budaya mereka senang melihat keunikankeunikan yang ada dan juga memiliki karakter spontan dengan apa yang mereka lihat di situlah kadang anak-anak melihat sesetau yng baru maka langsung spontan bertanya tentang sesutau yang baru

\section{Pengertian karakter toleransi}

Kata "toleransi" berarti sifat atau sikap toleran. Kata toleran sendiri didefinisikan sebagai "bersifat atau bersikap menenggang (menghargai, membiarkan, membolehkan) pendirian (pendapat, pandangan, kepercayaan, kebiasaan, dan kelakuan) yang berbeda atau bertentangan dengan pendirian sendiri”

Istilah yang lazim dipergunakan sebagai padanan kata toleransi dalam bahasa Arab adalah . Kata ini pada dasarnya berarti al-jûd (kemuliaan) atau sa"at al-shadr (lapang dada) dan tasâhul (ramah, suka memaafkan) (Kamus Al-Munawwir, 1997: 675). Makna ini selanjutnya berkembang menjadi sikap lapang dada/terbuka (welcome) dalam menghadapi perbedaan yang bersumber dari kepribadian yang mulia. ${ }^{11}$

Toleransi adalah sikap saling menghargai, menghormati keragaman budaya, menghargai perbedaan kebebasan bereksperesi, termasuk dalam keyakinan orang lain agama.

Jadi, toleransi adalah saling menghargai dalam perbedaan, baik dari budaya, agama, maupun keyakinan. Yang dimaksud keyakinan di sini menghargai apa yang mereka percayai. Serta tidak saling mengjelek-jelekkan dalam perbedaan.

\footnotetext{
${ }^{10}$ Syamsu Yusuf L.N, dan Nani M Sugandhi," Perkembangan Peserta Didik” (Jakarta: Rajawali Pres,2013) Cet Ke IV h. 48-50

${ }^{11}$ Ika Budianti Toleransi Dalam Bahasa Arab Dalam:https://www.scribd.com/doc/290109444/ToleransiDalam-Bahasa-Arab-Disebdi akses di Metro tanggal 01 Agustus 2019 Pukul 10:30 WIB
} 
Beberapa bentuk sikap toleran dalam melaksanakan dakwah di antaranya adalah sebagai berikut.

a) Toleran dengan persaudaraan sesama muslim. Berkaitan dengan hubungan toleransi dengan persaudaraan sesama muslim, dalam hal ini Allah SWT berfirman yang artinya, "orang-orang beriman itu sesungguhnya bersaudara. Sebab itu damaikanlah (perbaikilah hubungan) antara kedua saudaramu itu dan takutlah terhadap Allah, supaya kamu mendapat rahmat (QS. Al-Hujurat: 10). Dalam ayat ini orang mukmin bersaudara dan Allah memerintahkan untuk melakukan islah (mendamaikannya untuk perbaikan hubungan) jika seandainya terjadi kesalahpahaman di antara mereka.

b) Toleran antar ummat beragama. Toleransi antar ummat beragama dapat dimaknai sebagai suatu sikap untuk dapat hidup bersama masyarakat penganut agama lain dengan memiliki kebebasan untuk menjalankan prinsip-prinsip keagamaan (ibadah) masing-masing.

c) Toleran dalam kehidupan berkeluarga. Sikap toleransi sangat dibutuhkan untuk ditumbuhkan dalam keluarga agar terbentuk suasana keluarga yang harmonis. Setiap anggota keluarga memiliki peran dan fungsinya masing-masing dalam keluarga.

d) Toleransi dalam kehidupan bermasyarakat. Toleransi adalah sebuah bentuk sikap akibat adanya persinggungan hak-hak individu dalam masyarakat atau hak-hak masyarakat dalam negara. Jadi, dapat dikatakan bahwa toleransi adalah sebuah solusi bagi adanya perbenturan hak-hak.

e) Toleransi dalam kehidupan berbangsa dan bernegara. Kehidupan berbangsa dan bernegara pada hakikatnya merupakan kehidupan masyarakat bangsa. Di dalamnya terdapat kehidupan berbagai macam adat istiadat, kebudayaan, suku bangsa, pemelukagama, dan penganut kepercayaan yang berbeda-beda ${ }^{12}$

Teori yang dikembangkan Tillman (2004) tentang butir-butir refleksi dari karakter toleransi tersebut adalah (a) kedamaian adalah tujuan; (b) toleransi adalah terbuka dan reseptif pada indahnya perbedaan; (c) toleransi menghargai individu dan perbedaan; (d) toleransi adalah saling menghargai satu sama lain; (e) benih dari intoleransi adalah ketakutan dan ketidakpedulian; (f) benih dari toleransi adalah cinta; (g) jika tidak cinta tidak ada toleransi; (h) yang tahu menghargai kebaikan dalam diri orang lain dan situasi memiliki toleransi; (i) toleransi

\footnotetext{
${ }^{12}$ Hanafi Op.Cit h.179-182
} 
berarti menghadapi situasi sulit; dan (j) toleransi terhadap ketidaknyamanan hidup dengan membiarkan berlalu, ringan, dan membiarkan orang lain. Butir-butir refleksi karakter toleransi tersebut akan mengantarkan kedamaian antar individu di dunia. Temuan dari studi literatur mengungkap aspek dan indikator karakter toleransi yaitu kedamaian, menghargai perbedaan dan individu, serta kesadaran. ${ }^{13}$

Dari paparan pengertian diatas dapat di simpulkan bahwa karakter toleransi adalah saling mennghargai satu sama lain dari setiap perbedaan individu kelompok maupun masyarakat baik perbedaan suku, bangsa, agama ras dan perbedaan-perbedaan lain dalam kehidupan sehari-hari di lingkungan masayarakat.

Tabel 1. Aspek Karakter Toleransi

\begin{tabular}{|l|l|l|}
\hline No & \multicolumn{1}{|c|}{$\begin{array}{l}\text { Aspek } \\
\text { Toleransi }\end{array}$} & \multicolumn{1}{|c|}{ Indikator Toleransi } \\
\hline 1. & Kedamaian & $\begin{array}{l}\text { a. Peduli } \\
\text { b. Ketidaktakutan } \\
\text { c. Cinta }\end{array}$ \\
\hline 2. & $\begin{array}{l}\text { Mengaharg } \\
\text { ai Pebedaan } \\
\text { dan }\end{array}$ & $\begin{array}{l}\text { a. Saling menghargai satu sama lain } \\
\text { b. Menghargai perbedaan orang lain } \\
\text { c. Menghargai diri sendiri }\end{array}$ \\
\hline 3 & Kesadaran & $\begin{array}{l}\text { a. Menghargai kebaikan orang lain } \\
\text { b. Terbuka } \\
\text { c. } \text { Reseptif } \\
\text { d. Kenyamanan dalam kehidupan } \\
\text { e. Kenyamanan dengan orang lain }\end{array}$ \\
\hline
\end{tabular}

${ }^{13}$ Agus Supriyanto \& Amen wahyudi " Skala Karakter toleransi konsep dan operasional aspek kedamaian, menghargai dan kesadaran individu” (UAD Yogyakarta:Jurnal Ilmiyan Coussellia,November 2107) Volume 7 No 2 h. $65-66$ 


\section{Pendidikan Multikultural di perumahan PNS Kota Metro}

Pendidikan multikultural di perumahan pns kota merupakan sebuah kegiatan yang di lakukan sehari-hari di setiap komunikasi dan social anak usia dini dalam kehidupan sehari hari, di lingungan perumahan pns terdapat beraneka ragam suku bangsa dan agama. Pada awal anak usia dini bersosialisasi mereka bingung dengan gaya bahasa temannya yang berbeda-beda misalnya, anak yang berasal dari suku batak yang berbicaranya keras, anak yang dari suku lampung memiliki gaya berbicara yang cepat, anak dari suku jawa yang kebanyakan memiliki logat yang medok, anak dari suku bali yang tidak bisa mengucapkan huruf $(\mathrm{T})$, suku batak yang kalu bicara dengan nada yang tinggi seperti orang marah dan lain sebagainya. Pendidikan multikultural berguna untuk menanamkan nilai karakter toleransi pada anak-anak di lingkungan perumahan PNS kota metro, karena bnyaknya suku dan agama yang beragam anak-anak mungkin sering spontan bertanya mengapa si A kalau bicara suaranya keras-keras seperti oranf marah-marah. Mengapa si B kalu bicara terlalu cepat seperti itu dan rasa ingin tahu mereka juga makin tinggi. sehingga beberapa warga mulai mengenalkan pendidikan multicultural pada anakanak mereka misalnya keluarga ibu puspa yang beragama Islam dari suku banten mempunyai anak usia 4 tahun, saya bertanya kepada ibu puspa bagaimana ibu puspa mengenalkan pendidikan multicultural pada anak beliauyang berguna untuk menanamkan nilai toleransi pada anak usia dini, kemudian ibu puspa menceritakan kepada saya bagaimana beliau menanamkan pendidikan multicultural kepada anaknya beiau berkata berkata,

"saya mengajarkan pendidikan multicultural dan menanamkan nilai toleransi sebenarnya dari pertanyaan anak saya yang spontanitas saya pernah mendapatkan pertanyaan dari anak-anak saya dengan pertanyaan-pertanyaan yang mungkin rasa ingin tahu mereka cukup tinggi sang anak bertanya kalau kawannya yang bernama si (A) kenapa selalu bicara denagn teriak-teriak lalu ibu puspapun menjawab pertanyaan anaknya dan menjelasknya bahwa kawannya yang bernama (A) itu adlah saudara kita dari suku batak yang mana mereka kalau bicara memang dengan nada yang tingi namun bukan berarti kawanmu itu marah apa benci dengan kamu nak, jadi jangan takut kalau kawannya ngajak bicara ataupun ngajak bermain karena kawanmu anak yang baik dan suka berbagi" 14

Dari hasil wawancara dengan ibu puspa di sini ada pendidikan multicultural dan penanaman toleransi yang mana ibu puspa mengenalkan salah satu suku di Indonesia dan menanamkan toleransi pada ananya agar tetap berteman dengan salah satu kawannya yang

\footnotetext{
${ }^{14}$ Wawancara langsung dengan ibu Puspa winarti lokasi di halaman rumah ibu puspa perumahan PNS blok C2 No 16, 02 pada hari sabtu 02 maret2019 pukul 17.00
}

Volume 1 No 1 2019, J-Sanak_Jurnal Kajian Anak | 48 
menurut sang anak suka marah-marahena suaranya yang keras. Masih bnyak lagi pendidikan multicultural yang di lakukan dalam kegiatan sehari-hari seperti yang di lakukan wawancara dengan ibu melda yang dari suku lampung beragama Islam yang memiliki anak usia 4 tahun dan 1 tahun saya bertanya kepada ibu melda bagaimana beliau mngajarkan pendidikan multicultural guna untuk menguatkan nilai karater toleransi pada anak usia dini beliau mengatakan kepada saya:

“anak saya sering bertannya,"(mama kenapa kk' gratia tidak pernah ikut mengaji di rumahnya ada pohon yang ada lampu-lampunya terus kalu mau makan doanya tidak sama dengan kita dan kalau ngomong berbeda dengan kita)" sayapun menjelaskan bahwa kalau kk'gratia itu beragama Kristen katolik yang memang berdo'anya verbeda dengan kita dan kalau kk' gratia ngomongnya beda dengan kita itu karena dari suku jawa jogja yang memiliki khas logat dan gaya bahasa yang seperti itu, dan kk' gratia tidak ikut mengaji di mushola karena ibadahnya di hari minggu pagi di gereja, jadi kalau hari minggu pagi tidak boleh mengajak kk' gratia main karena mau pergi beribadah dan pohon yang ada lampu-lampu di rumahnya adalah pohon natal yang ada di setiap hari raya umat Kristen seperti kita misalnya kalu lebaran idul fitri ada gambar ketupat dan bedug di mana-mana"15

Dari wawancara di atas sudah di jelaskan bahwa kita menanamkan toleransi pada anak usia dini sangatlah penting dengan mengajarkan nilai-nilai toleransi pada anak meskipun kawannya berbeda agama tetap saling berkawan dengan anak-nak di sekitar rumahnya dan tidak mengganggu ketika kawannya yang berbeda suku dan agama akan menjalankan ibadah yang di anutnya untuk menanamkan nilai toleransi

Penulis juga melakukan wawancara lagi dengan salah satu warga perumahan PNS yaitu dengan Ibu Fitri sinurat yang bersuku batak, agama Kristen memikiki anak usia 5 tahun dan 1 tahun saya bertanya kepada beliau bagaimana memberikan pendidikan multicultural pada anak usia dini untuk menguatkan nilai karakter toleransi pada anak beliau mengatakan kepada saya,

"saya mengajarkan anak tentang pendidikan multicultural dan toleransi karena lingkungan saya beda agama dan suku depan saya suku bali dan beragama hindu anak saya sering melihat janur kuning dan patung di depan rumahmya lengkap dengan sesaji awalnya anak saya mengira itu adalah mainan ataupun makanan yang boleh di makan makanya anak saya sering masuk ke halaman rumah tetangga yang beragama hindu namun saya menjelakan pada anak saya bahwa itu bukan makanan yang boleh dimakan oleh manusia dan jawan merusak janurjanur di depan rumahnya karena itu susah bikinnya dan saya juga menjelaskan ttentang agam

\footnotetext{
${ }^{15}$ Wawancara langsung dengan ibu melda agustina, lokasi ters rumah ibu melda agustina perumahan PNS bok C2 No15. Pada hari sabtu 02 maret 2019 pukul 19:30
}

Volume 1 No 1 2019, J-Sanak_Jurnal Kajian Anak | 49 
hindu itu cata beribadahnya dengan sesaji yang terletak di depan rumahnya dan jangan mengganggu jika para tetangga sedang beribadah"16

Penjelasan dari ibu fitri yang mengatakan bahwa sebelum anak beliau bertanya tentang agama yng di anut oleh tetangga depan rumahnya beliau lebih dahulu member penjelasan kepada anak beliau bawa mereka beragama hindu dan bersuku bali yang berbeda dengan agama yang di anut oleh keluarga bu fitri agar anaknya tidak mengganggu dan merusak sesuatu yang ada di depan rumah orang yang beragama hindu.

Pendidikan multicultural di perumahan PNS banyak cara dalam melaksanakannya selain pribadi setiap individu yang mengajarkan pada anaknya mengenai pendidikan multicultural masyarakat di lingkungan perumahan PNS juga menerapkan pendidikan multicultural dan toleransi dengan diadakannya perpustakaan keliling cahaya ilmi yang berkeliling pada setiap selasa, jum'at dan minggu bergantian pada setiap gang, dlam kegiatan membaca tersebut semua anak bermain bersama membaca bersama tanpa membedakan satu sama lain baik suku bangsa dan agama, bapak andriansya sebagai pengelola perpustakaan keliling mengatakan bahwa" saya mengadakan perpustakaan keliling selain bermanfaat agar anak rajin membaca juga untuk meningkatkan kedekatan anak-anak satu dengan yang lain dan saling menyayangi dan menghargai mereka supaya nilai karakter toleransi sudha tertanam di jiwa mereka dan dianatara mereka yang berbeda suku agama bahkan status social tidak menjadi masalah ketika mereka di masyarakat dan tetap mebuat mereka dekat dan saling menghargai menjadi anak-anak yang penuh kasih saying dan menghargai orang lain.

Karekteristik pada anak usia dini adalah rasa ingin tahu yang cukup tinggi dan spontanitas pertanyaan-pertanyaan yang di ucapakan anak, sehingga dari karakteristik anak usia dini secara tidak langsung dan kondisi lingkungan yang berbeda beda suku dan agama menjadi alasan dasar bagi warga perumahan PNS kota metro Lampung dalam menjalankan pendidikan multicultural pada anak usia dini dengan menanamkan nilai karakter toleransi pada anak usia dini sehingga mereka bisa saling menyayangi satu sama lain meskipun hidup yang berdampingan satu dan yang lainnya berbeda sehingga anak-anak dapat hidup denngan penuh kedamaian di lingkungan masyarakat tanpa saling mengejek ataupon menolok suku, bangsa dan agama dan sudah tertanam juga Bineka tunggal ika di lingkungan perumahan PNS KOTA Metro lampung

\footnotetext{
${ }^{16}$ Wawancara Ibu fitri sinurat di depan gang prabu II perumahan PNS kota Metro pada hari munggu tanggal 6 juli 2019 pukul 17:30 WIB
} 


\section{KESIMPULAN}

Penelitian ini dapat disimpulkan bahwa di lingkungan yang beragam dan memiliki kebiasaan berbeda antara satu dan lainnya, sehingga pendidikan multicultural sangat penting untuk diajarkan pada anak usia dini. Anak usia dini memiliki karakteristik yang kuat yaitu rasa ingin tahu yang cukup tinggi dan spontanitas bertanya mengai hal-hal yang baru dilihatnya ataupun berbeda dalam kebiasaan sehari hari, dengan demikian masyarakat di perumahan PNS kota Metro mengajarkan pendidikan multicultural secara individi atas dasar rasa ingin taahu anak yang cukup tinggi dan spontanitas pertanyaan dari anak dan juga secara kelompok melalui perpustakaan keliling agar anak-anak dapat berkumpul bersama-sama dan tidak membedakan status social baik yang kaya attaupun yang miskin, yang satu agama ataupun yang beda agama yang satu suku maupun yang beda suku semuanya diciptakan untuk kebersamaan dan kerukunan dalam kegiatan bermain sambil belajar membaca buku perpustakaan keliling, pengetahuan pendidikan multicultural pada anak bertujuan untuk menanamkan nilai karakter toleransi pada jiwa anak usia dini, dengan tertanamnya nilai toleransi pada anak usia dini anak-anak akan saling menghargai perbedaan antara satu dengan yang lain, saling mencintai tidak mudah untuk saling bermusuhan dalam urusan perbedaan baik suku ataupun agama dan tertanam pada jiwa anak usia dini dengan Bhineka Tunggal Ika.

\section{E. DAFTAR PUSTAKA}

Departemen Agama RI Alqur'an dan Terjemahnya, Bandung PT Cordoba, 2013

Kamus Besar Bahasa Indonesia Daring (Dalam Jaringan), Mansur, Pendidikan Anak Usia Dini Dalam Islam, Pustaka Pelajar, Yogyakarta, 2005.

Martimin Sabrin dan Jamilah sanan, "Panduan pendidikan Anak Usia Dini" Jakarta: Gaung Persada press, 2010

Undang-Undang Sisdiknas 2003, Bab I Pasal I Ayat I dan Bab 2 Pasal 3

Suryana, Dadan,” Pendidikan Anak Usia Dini Teori dan praktik, Padang:UNP Pres,2013

Syamsul Yusuf L.N, dan Nani M Sugandhi," Perkembangan Peserta Didik" Jakarta: Rajawali Pres, 2013

Agus Supriyanto \& Amen wahyudi Skala Karakter toleransi konsep dan operasional aspek kedamaian, menghargai dan kesadaran individu UAD Yogyakarta: Jurnal Ilmiyan Coussellia,November 2107) Volume 7 No 2

Hanafi," Saintifika Islamica :Jurnal Kajian Islam UIN Jogjakarta, Saintifika Islamica volume 3 no2 perode juli-Desember 2016 ISSN:Vol 32407No.- 053X2 h. 170 
Zakwan Priaji, Dalam: http://zakwaan-priaji.blogspot.com/2013/07/pengertian-pendidikanmultikultural.html, metro 20 Agustus 2019, 14.00

Dosen sosiologi.Com Dalam: http://dosensosiologi.com/pengertian-multikultural-latar-belakangciri-dan-bentuk, di akses pada 03 agustus 2019, pukul 09:30 WIB.

Ika Budianti Toleransi Dalam Arab Dalam:https://www.scribd.com/doc/290109444/Toleransi-Dalam-Bahasa-Arab-Disebdi akses di Metro tanggal 01 Agustus 2019 Pukul 10:30 WIB.

Musthofa dalam https://pengertian multikultural menurut para ahliid.wikipedia.org/wi diakses di metro pada tanggal 05 Agustus 2019 pukul 09:00 WIB 